\title{
Reference values for the 6-min walk test in healthy middle-aged and older adults: from the total distance traveled to physiological responses
}

Valores de referência para o teste de caminhada de 6 minutos em adultos saudáveis de meia-idade e idosos: da distância total percorrida às respostas fisiológicas

Valores de referencia para la prueba de caminata de 6 minutos en adultos sanos de mediana edad y de edad avanzada: de la distancia total a las respuestas fisiológicas

Evandro Fornias Sperandio ${ }^{[a]}$, Ricardo Luís Fernandes Guerra ${ }^{[a]}$, Marcello Romiti ${ }^{[b]}$, Antônio Ricardo de Toledo Gagliardi $\circledast^{[b]}$, Rodolfo Leite Arantes $\oplus^{[b]}$, Victor Zuniga Dourado $₫[a]$

[a] Universidade Federal de São Paulo (Unifesp), Santos, SP, Brazil

${ }^{[b]}$ Instituto de Medicina Cardiovascular (Angiocorpore), Santos, SP, Brazil

\section{Abstract}

Introduction: Physiological responses to the 6-min walk test (6MWT) have been increasingly evaluated in patients with cardiopulmonary diseases. However, previous studies did not include healthy persons. Objective: To evaluate the intensity of 6MWT, to develop a series of predictive equations for the physiological variables

\footnotetext{
* EFS: PhD, e-mail: evandrosperandio@yahoo.com RLFG: PhD, e-mail: ricoguerra06@yahoo.com.br MR: PhD, e-mail: marcello.romiti@angiocorpore.com.br ARTG: PhD, e-mail: antoniogagliardi@ig.com.br RLA: PhD, e-mail: arantes.dr@gmail.com VZD: PhD, e-mail: victor.dourado@unifesp.br
} 
and to test their reliability in healthy middle-aged and older adults. Method: We evaluated 102 non-trained healthy adults (54 women, aged $61 \pm 10$ years) and a cross-validation sample of 30 participants. We measured physiological responses to the 6MWT and a cardiopulmonary exercise testing (CPET) on a treadmill. Results: The $\mathrm{R}^{2}$ values for regression analysis adjusted by age, body mass, stature, and sex ranged from 0.25 for heart rate and 0.46 for peak $\dot{\mathrm{V}} \mathrm{O}_{2}$. The $6 \mathrm{MWT}$ distance and $6 \mathrm{MWT}$ peak $\dot{\mathrm{V}} \mathrm{O}_{2}$ represented $110 \pm 10 \%$ and $102 \pm 15 \%$ of the predicted values, respectively, using our equations. The intensity of $6 \mathrm{MWT}$ corresponded to $72 \pm 13 \%$ of the peak $\mathrm{O}_{2}$ and $78 \pm 23 \%$ of the peak HR in the CPET. Peak $\mathrm{VO}_{2}$ in the CPET was adequately predicted by 6MWT peak $\dot{\mathrm{VO}}_{2}\left(\mathrm{R}^{2}=0.76\right)$ and $6 \mathrm{MWD}\left(\mathrm{R}^{2}=0.54\right)$. Conclusion: The 6MWT represents a moderate to high-intensity test in middle-aged and older healthy adults and is valid for assessing maximal aerobic exercise capacity. Physiological responses to the 6MWT may be adequately predicted with a combination of anthropometrics and demographics.

Keywords: Walking. Reference Values. Exercise.

\section{Resumo}

Introdução: As respostas fisiológicas ao teste de caminhada de 6 minutos (TC6) têm sido cada vez mais avaliadas em pacientes com doenças cardiopulmonares. No entanto, estudos anteriores não incluíram pessoas saudáveis. Objetivo: Avaliar a intensidade do TC6, desenvolver uma série de equações preditivas para as variáveis fisiológicas e testar sua confiabilidade em indivíduos saudáveis de meia-idade e idosos. Método: Avaliamos 102 adultos saudáveis não treinados (54 mulheres, com idade de $61 \pm 10$ anos) e uma amostra de validação cruzada de 30 participantes. Nós medimos as respostas fisiológicas ao TC6 e ao teste de exercício cardiopulmonar (TECP) em esteira rolante. Resultados: 0 s valores de R2 para análise de regressão ajustados por idade, massa corporal, estatura e sexo variaram de 0,25 para frequência cardíaca e 0,46 para pico $\dot{\mathrm{V}} \mathrm{O}_{2}$. A distância e o $\dot{\mathrm{V}} \mathrm{O}_{2}$ no TC6 representou $110 \pm 10 \%$ e $102 \pm 15 \%$ dos valores previstos, respectivamente, usando nossas equações. A intensidade do TC6 correspondeu a $72 \pm 13 \%$ do pico de $\dot{\mathrm{V}}_{2}$ e $78 \pm 23 \%$ do pico de frequência cardíaca no TECP. O pico de $\dot{\mathrm{V}} \mathrm{O}_{2}$ no TECP foi adequadamente previsto pelo pico de $\mathrm{V}_{2}(R 2=0,76)$ e pela distância no TC6 $(R 2=0,54)$. Conclusão: O TC6 representa um teste de intensidade moderada a alta em adultos saudáveis de meia-idade e idosos e é válido para avaliar a capacidade máxima de exercício aeróbico. Respostas fisiológicas ao TC6 podem ser adequadamente previstas com uma combinação de dados antropométricos e demográficos.

Palavras-chave: Caminhada. Valores de Referência. Exercício.

\section{Resumen}

Introducción: Las respuestas fisiológicas a la prueba de caminata de 6 minutos (PC6M) se han evaluado cada vez más en pacientes con enfermedades cardiopulmonares. Sin embargo, estudios anteriores no incluyeron a personas sanas. Objetivo: Evaluar la intensidad de la PC6M, desarrollar una serie de ecuaciones predictivas para las variables fisiológicas y probar su confiabilidad en individuos sanos de mediana edad y en ancianos. Método: Evaluamos 102 adultos sanos no entrenados (54 mujeres, con edad de $61 \pm 10$ años) y una muestra de validación cruzada de 30 participantes. Medimos las respuestas fisiológicas a la PC6M y a una prueba de ejercicio cardiopulmonar (PECP) en la cinta de correr. Resultados: Los valores de R2 para análisis de regresión ajustados por edad, masa corporal, estatura y sexo variaron de 0,25 para frecuencia cardíaca y 0,46 para pico O2. La distancia y el $\mathrm{V}_{2}$ en la PC6M representaron $110 \pm 10 \%$ y $102 \pm 15 \%$ de los valores previstos, respectivamente, usando nuestras ecuaciones. La intensidad de la PC6M correspondió a $72 \pm 13 \%$ del pico de $\dot{\mathrm{V}}_{2}$ y a $78 \pm 23 \%$ del pico de frecuencia cardiaca en la PECP. El pico de $\dot{\mathrm{VO}}_{2}$ en la PECP fue adecuadamente previsto por el pico de $\dot{\mathrm{V}}_{2}(R 2=0,76)$ y por la distancia en la PC6M $(R 2=0,54)$. Conclusión: La PC6M representa una prueba de intensidad moderada a alta en adultos sanos de mediana edad y en ancianos y es válida para evaluar la capacidad máxima de ejercicio aeróbico. Las respuestas fisiológicas a la PC6M pueden ser previstas con una combinación de datos antropométricos y demográficos.

Palabras clave: Caminata. Valores de Referencia. Ejercicio. 


\section{Introduction}

A more accurate assessment of physiological responses induced by exercise is extremely necessary in the clinical environment, especially concerning peak oxygen uptake $\left(\mathrm{V}_{2}\right)$. Patients with severe chronic cardiopulmonary diseases should perform cardiopulmonary exercise testing (CPET) as a routine assessment because alow peak $\dot{\mathrm{V}} \mathrm{O}_{2}$ may indicate the need for lung and/or heart transplantation [1]. Recently, the results of gas exchange assessment during a submaximal exercise were able to distinguish patients with pulmonary arterial hypertension from healthy individuals, as well as to stratify such patients according to the severity of disease [2]. Despite the widely validity of CPET, its application remains complex, expensive and dependent on highly trained professionals. Accordingly, simple and inexpensive ways for assessing aerobic exercise capacity should be investigated as complementary to CPET.

One of the greater advantages of the 6-minute walk test (6MWT) is its operational simplicity. The 6-min walk distance (6MWD) is often used as an index of cardiorespiratory fitness and has been validated in several populations of patients with chronic diseases [3-5]. Although the basic maneuver itself is easy to perform and gives rise to a limited number of physiologic measures, the physiological responses to the 6MWT have been evaluated with the aid of sophisticated telemetric gas analyzers for measuring exercise capacity in patients with chronic diseases. [6-8]. However, there is little information regarding intensity and physiological responses to the field walking tests in healthy individuals, especially in middle-aged adults and seniors. Accordingly, we hypothesized that the 6MWT may also be used in adults without chronic disease as a test of sufficient intensity to assess aerobic capacity in middle-aged adults and seniors.

Therefore, we aimed to evaluate the intensity of 6MWT in healthy middle-aged and older adults by comparing the main physiological variables obtained during the 6MWT with those obtained in CPET. Secondarily, we aimed to develop a series of simple predictive equations for the main physiological variables and test their reliability.

\section{Material and Methods}

Participants

We conducted a cross-sectional study in 132 healthy adults aged 40 to 88 years old. The local Ethics
Committee approved the study, and all participants provided written informed consent.

We recruited a convenience sample. The volunteers were students and employees from our University and from our University Hospital, both located in Santos, SP, Brazil, as well as residents of the surrounding community. Participants who did not have a body mass index (BMI) $>35 \mathrm{~kg} / \mathrm{m}^{2}$, require a walking aid, showed abnormal post-bronchodilator lung function [9], reported having cardiorespiratory, metabolic, neuromuscular, or musculoskeletal disease, or were not current smokers were eligible for the analysis. Participants involved in more than 300 minutes/week of high-intensity exercises or sports were considered trained subjects and were also excluded from this study. Physical inactivity was considered as lack of at least 150 minutes/week of moderate to vigorous physical activity.

Potential participants underwent a series of evaluations over the course of 2 mornings. On day 1 , 102 participants completed a physical activity readiness questionnaire [10], a face-to-face interview based on the main cardiovascular risk factors, and a questionnaire on physical activity. They also underwent spirometry, handgrip strength (HGS) assessment, and measurements of anthropometry and body composition. Those who met the eligibility criteria then returned on day 2 and performed three 6MWTs with 30 min apart. A crossvalidation sample of 30 participants $(59 \pm 10$ years old; $77 \pm 14 \mathrm{~kg} ; 1.67 \pm 0.12 \mathrm{~m}$ ) underwent the same above-mentioned protocol plus a ramp CPET performed on a treadmill. We used this sample to apply reference equation as well as to investigate the intensity of 6MWT against the CPET results (Figure 1).

\section{Anthropometrics and body composition}

Body mass $(\mathrm{kg})$ and stature $(\mathrm{m})$ were measured with participants wearing light clothing and no shoes. The BMI $\left(\mathrm{kg} / \mathrm{m}^{2}\right)$ was then calculated. Body composition was assessed using a portable scale (TBF-310GS; Tanita, Arlington Heights, IL, USA), which had a tetra-polar bioimpedance system. Fat body mass (FBM), total body water, and lean body mass (LBM) were assessed using regression equations [11].

\section{Spirometry}

Spirometry was performed using a hand-held spirometer (Spiropalm; COSMED, Pavona di Albano, Italy) 
according to the criteria established by the ATS [9]. The forced expiratory volume in $1 \mathrm{~s}\left(\mathrm{FEV}_{1}\right)$, the forced vital capacity (FVC) and the $\mathrm{FEV}_{1} / \mathrm{FVC}$ ratio were quantified.

\section{Handgrip strength}

The HGS of the dominant side was assessed using a hydraulic dynamometer (HS5001; Carci, São Paulo, Brazil) according to the methods described by Mathiowetz et al. [12]. The greatest value of 3 attempts was selected for further analysis.

\section{6-min walk test}

Three 6MWTs were performed according to ATS standards [13] at 30-min intervals. The participants were instructed to walk as far as possible during a 6-min period down a 30-m hallway. Standardized verbal encouragement was provided to the participants every minute. Measured 6MWDs were registered for further analysis in meters and in percentage of reference values [14]. Before and after each test, the rate of perceived exertion (dyspnea and leg fatigue) was measured using a Borg CR10 scale [15].

Throughout the third 6MWT, expired gases were collected and analyzed with a commercially available portable telemetric gas analyzer $\left(\mathrm{K} 4 \mathrm{~b}^{2}\right.$; COSMED, Pavona di Albano, Italy). The gas analyzer (the entire weight of which was less than $1 \mathrm{~kg}$ ) was attached to the participants by shoulder straps, allowing free movement with no discomfort. Room air, reference gas, 3-L syringe and delay calibrations were carried out following the manufacturer's recommendations.

The following variables were obtained at the peak of the 6MWT: pulmonary oxygen uptake $\left(\dot{\mathrm{V}}_{2}\right)$, carbon dioxide production $\left(\dot{\mathrm{V}} \mathrm{CO}_{2}\right)$, heart rate (HR), and minute ventilation ( $\dot{\mathrm{V} E}$ ). Data were filtered every $15 \mathrm{~s}$.

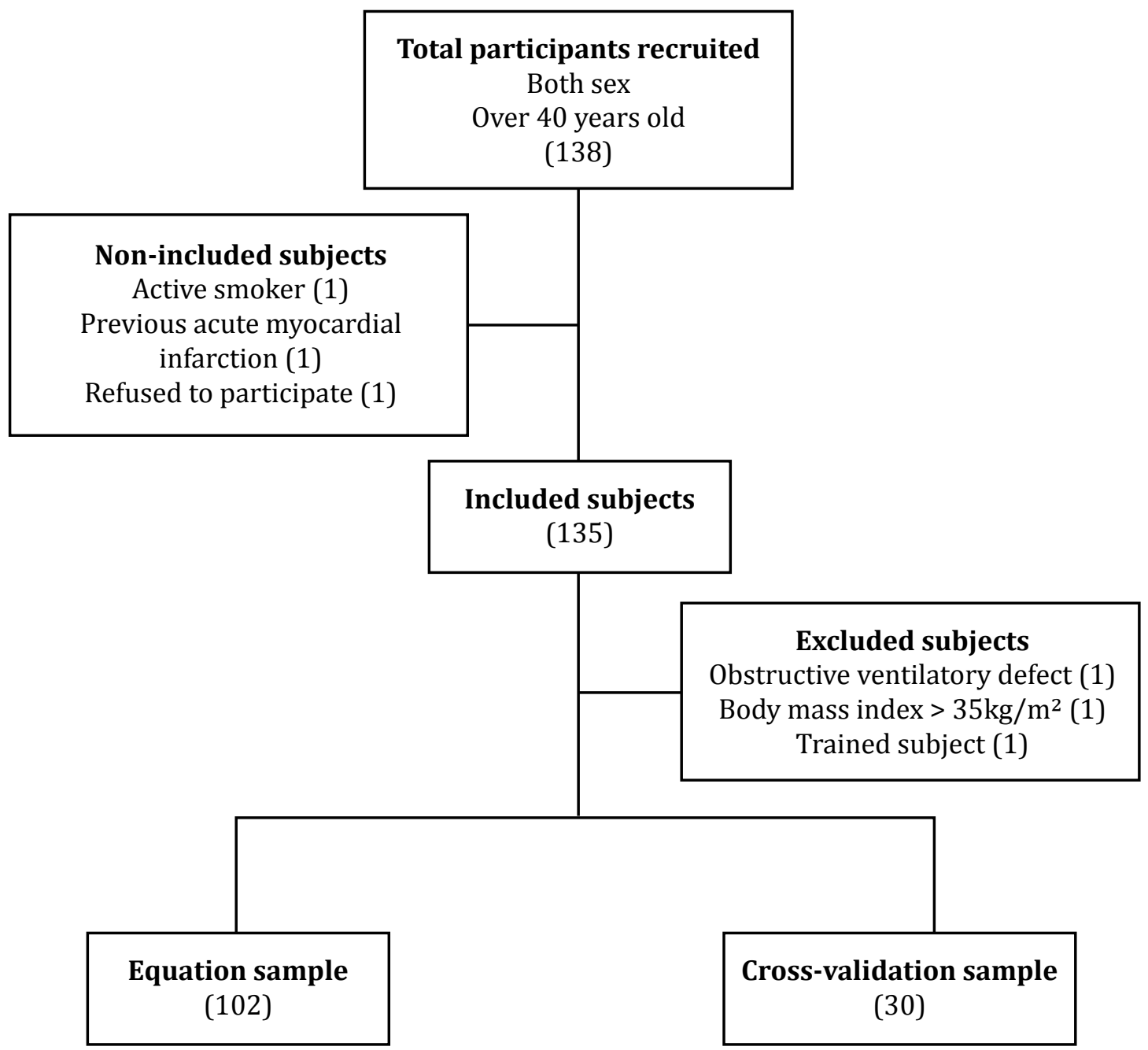

Figure 1 - Flowchart of included and excluded participants. 


\section{Cardiopulmonary exercise testing}

The CPET was performed on a treadmill (ATL, Imbramed, Porto Alegre, RS, Brazil) in a separated day in the cross-validation sample $(n=30)$. The laboratory temperature was standardized in 22 degrees. Participants were instructed to avoid, in the day prior to the test, vigorous physical activity, caffeine and other stimulants, heavy diet to use proper clothing in the day of assessment. The subjects underwent a ramp protocol. After 3-min of rest, the velocity and inclination were slightly incremented individually until exhaustion according to predicted peak $\dot{\mathrm{V}} \mathrm{O}_{2}$.

Ventilatory, cardiovascular and metabolic responses were continuously monitored during the CPET by a gas analyzer (Quark PFT/CPET, Cosmed, Pavona di Albano, Italy). The following variables were collected and analyzed: heart rate (HR), oxygen uptake $\left(\mathrm{V}_{2}\right)$, carbon dioxide production $\left(\mathrm{V}^{\prime} \mathrm{CO}_{2}\right)$, and expired minute volume ( $\left.\mathrm{V}^{\prime} \mathrm{E}\right)$. The average $\mathrm{V}_{2}$ obtained in the last $15 \mathrm{~s}$ of the test was considered peak $\dot{\mathrm{V}} \mathrm{O}_{2}$. Oxygen uptake at lactate threshold $\left(\mathrm{V}_{2} \mathrm{O}_{2} \mathrm{LT}\right)$ was estimated using both gas exchange $\mathrm{V}$-slope and ventilatory techniques as previously described [16].

Statistical analysis

Bivariate correlations were assessed by Pearson or Spearman coefficients depending on the distribution of data.

We used multiple linear regression analysis to describe the dependence of various physiological responses on many factors, including age, body mass, stature and sex. For $\dot{\mathrm{V}}_{2}$ we also fitted another 3 models as follows: the abovementioned variables; followed by HGS and body composition variables; and then with the 6MWD and 6MWD $\times$ body mass, in alternative prediction models.

The sample size was estimated based on the product between the number of variables included in the multiple regression model (i.e., age, body mass, stature, sex, HGS, FBM and LBM) and the minimum number of observations indicating at least 70 individuals to the development of a linear model with seven variables.

For variables that were highly collinear, we selected those with the greatest clinical utility. Fitted regression equations are typically shown both for the mean value and for the lower limit of normal (LLN), defined as 1.645 standard errors below the mean (the nominal $5^{\text {th }}$ percentile for the population).
To ensure that the 6MWD obtained in the third test, which was carried out with the gas analyzer, was not inferior to the 6MWD obtained in the second test conducted without the equipment, we evaluated the intraclass correlation coefficient (ICC) with its 95\% confidence interval (95\% CI) between these measures, and also compared their mean values using a paired Student's $t$-test. A Bland and Altman plot was developed to assess agreement between $3^{\text {rd }}$ and $2^{\text {nd }}$ 6MWD.

The reliability of our reference equations and the intensity of the 6MWT were evaluated in the second group of 30 adults (14 men; $52 \pm 10$ years old; $77 \pm 14 \mathrm{~g} ; 1.67 \pm 0.12 \mathrm{~cm} ; 27 \pm 4 \mathrm{~kg} / \mathrm{m}^{2}$ ). We compared the measured peak $\mathrm{V}_{2}$ and $6 \mathrm{MWD}$ with the predicted values derived from our abovementioned equations by means of Student's $t$-test and Bland and Altman plots. The intensity of the 6MWT was assessed using $t$-test comparing peak $\mathrm{HR}$ and peak $\dot{\mathrm{V}} \mathrm{O}_{2}$ in the 6MWT with peak $\mathrm{HR}$ and peak $\dot{\mathrm{V}} \mathrm{O}_{2}$ in the CPET. We also compared peak $\dot{\mathrm{V}} \mathrm{O}_{2}$ in the 6MWT with $\dot{\mathrm{V}} \mathrm{O}_{2} \mathrm{LT}$.

Unless otherwise specified, we used a 2-tailed p-value $<0.05$ to define statistical significance.

\section{Results}

One hundred and two participants (54 women, $61 \pm 10$ years old) composed the main sample of this study. No participant presented abnormal spirometric values (Table 1). Thirty-one percent of the participants were considered physically inactive. The remaining participants were considered physically active, but still non-trained. Measured 6MWD represented $108 \pm 10 \%$ of the predicted values.

Table 1-General characteristics of the studied sample

\begin{tabular}{lcccc}
\hline & \multicolumn{3}{c}{ Females $(\mathbf{n}=\mathbf{5 4})$} & \multicolumn{2}{c}{ Males $(\mathbf{n}=\mathbf{4 8})$} \\
\hline & Mean & SD & Mean & SD \\
\hline Age $(\mathrm{yr})$ & 62 & 9 & 60 & 8 \\
Body mass $(\mathrm{kg})^{*}$ & 69 & 13 & 81 & 13 \\
Stature $(\mathrm{m})^{*}$ & 1.57 & 0.06 & 1.71 & 0.06 \\
BMI $\left(\mathrm{kg} / \mathrm{m}^{2}\right)$ & 28 & 5 & 27 & 3 \\
FBM $(\mathrm{kg})^{*}$ & 31 & 9 & 19 & 7 \\
FBM $(\%$ of total)* & 38 & 6 & 24 & 5 \\
LBM $(\mathrm{kg})^{*}$ & 44 & 4 & 58 & 7 \\
LBM $(\%$ of total)* & 59 & 6 & 75 & 5 \\
LBM $(\% \mathrm{pred})$. & 101 & 6 & 104 & 5 \\
LBMI $\left(\mathrm{kg} / \mathrm{m}^{2}\right)^{*}$ & 18 & 10 & 21 & 10 \\
HGS $(\mathrm{kgf})^{*}$ & 25 & 5 & 40 & 7 \\
\hline
\end{tabular}

Note: ${ }^{{ } p}<0.05$ : females vs. males; $\mathrm{BMI}=$ body mass index; $\mathrm{FBM}=$ fat body mass; $\mathrm{LBM}=$ lean body mass; $\mathrm{LBMI}=$ lean body mass index; HGS = handgrip strength. 
At the end of the third test, the HR was $80 \pm 13 \%$ of maximal estimated (220 - age). The peak $\dot{\mathrm{V}} \mathrm{O}_{2}$ in absolute values was $22 \pm 5 \mathrm{~mL} \cdot \mathrm{min}^{-1} \cdot \mathrm{kg}^{-1}$. The reliability between the second and third 6MWD was excellent (ICC, 0.959; 95\%CI, 0.935-0.962), and no significant difference between the mean values was observed $\left(2^{\text {nd }} 6 \mathrm{MWD}=569 \pm 79 \mathrm{~m}\right.$ vs. $\left.3^{\text {rd }} 6 \mathrm{MWD}=568 \pm 82 \mathrm{~m}\right)$. The agreement between $3^{\text {rd }}$ and $2^{\text {nd }} 6 \mathrm{MWD}$ was adequate (mean difference, -3.36 : $95 \%$ confidence interval, -59.56 to 37.05 ).

The time course (i.e., kinetics) of the main physiological responses to the 6MWT was similar to that described for a constant workload exercise test performed in a laboratory (Figure 2).
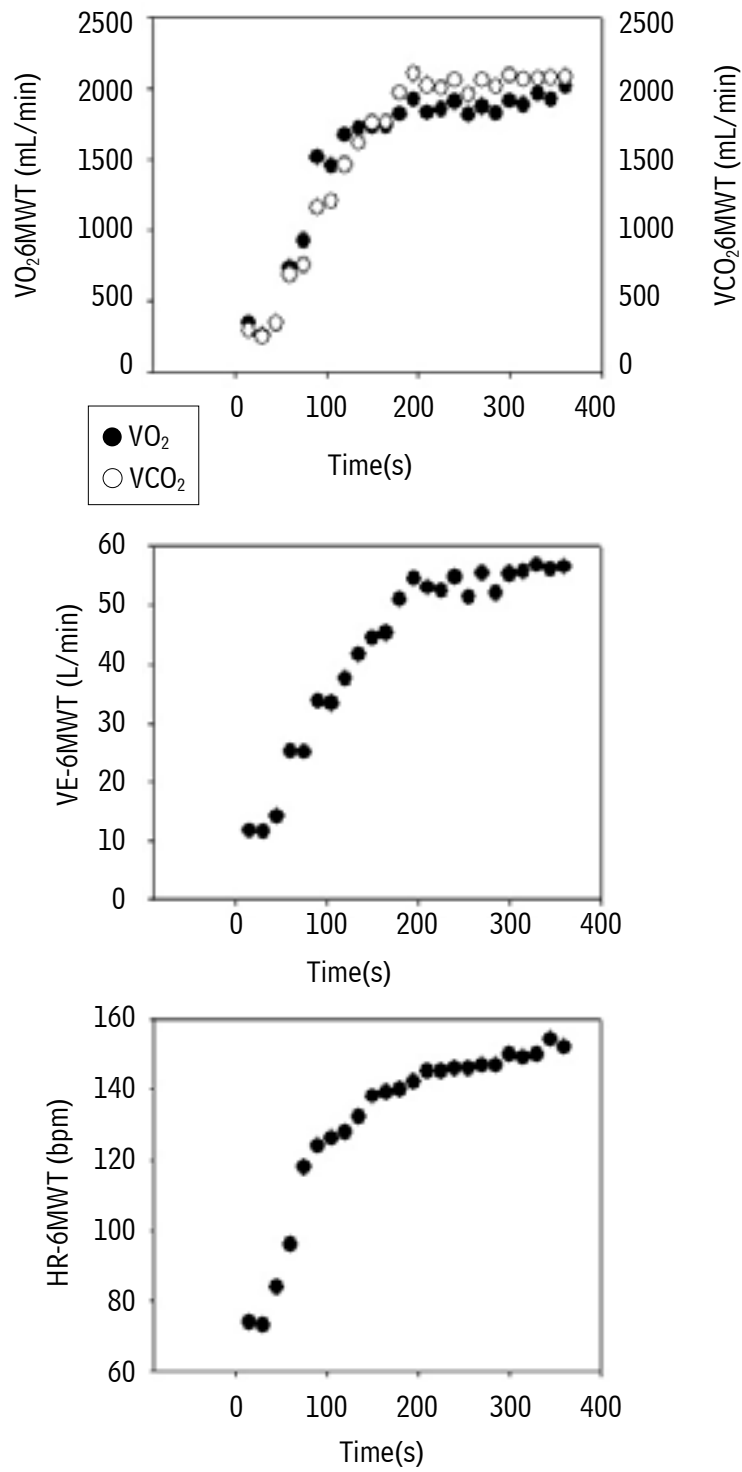

Figure 2 - Typical example of physiological responses to the 6-min walk test (6MWT). A - oxygen uptake $\left(\mathrm{V}_{2}\right)$ and carbon dioxide production $\left(\mathrm{V}_{\mathrm{CO}}\right)$; $\mathrm{B}-$ minute ventilation (VE); and $\mathrm{C}$ - heart rate (HR).
The $\mathrm{R}^{2}$ values for regression analysis that predicted physiological variables as a function of age, body mass, stature and sex ranged, for example, from 0.25 for HR and 0.65 for 6MWD in such models.

The models including LBM, FBM and HGS were unable to increase the $\mathrm{R}^{2}$ values for predicting peak $\dot{\mathrm{V}} \mathrm{O}_{2}$ during the 6MWT appreciably. On the other hand, the models that included LBM and FBM and HGS increased the $\mathrm{R}^{2}$ values for the $6 \mathrm{MWD}$ by $6 \%$ and $9 \%$, respectively.

The linear regression models derived the following predictive equations:

Equation 1:

$$
\begin{gathered}
\dot{\mathrm{V}} \mathrm{E}_{\mathrm{L} / \mathrm{min}}=-28.6-\left(0.2 \times \text { age }_{\text {years }}\right)+ \\
+(0.1 \times \text { body mass } \\
\mathrm{kg})+\left(48.4 \times \text { stature }_{\mathrm{m}}\right)+ \\
+(4.7 \times \mathrm{sex})
\end{gathered}
$$

Equation 2:

$$
\begin{gathered}
\mathrm{HR}_{\mathrm{bpm}}=195.9-\left(1.1 \times \text { age }_{\text {years }}\right)- \\
-\left(0.3 \times \text { body }_{\text {mass }} \mathrm{kg}\right)+\left(18.5 \times \text { stature }_{\mathrm{m}}\right)- \\
-(13.8 \times \text { sex })
\end{gathered}
$$

Equation 3:

$$
\begin{gathered}
\dot{\mathrm{V}} \mathrm{CO}_{2 \mathrm{~mL} / \mathrm{min}}=-400.8-\left(11.6 \times \text { age }_{\text {years }}\right)+ \\
+\left(4.1 \times \text { body mass }_{\mathrm{kg}}\right)+\left(1316.1 \times \text { stature }_{\mathrm{m}}\right)+ \\
+(180.9 \times \text { sex })
\end{gathered}
$$

Equation 4:

$$
\begin{aligned}
& \dot{\mathrm{V}} \mathrm{O}_{2 \mathrm{~mL} / \mathrm{min}}=-400.8-\left(11.6 \times \text { age }_{\text {years }}\right)+
\end{aligned}
$$

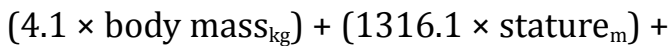

$$
\begin{aligned}
& +(180.9 \times \text { sex }) \text {; } \\
& \text { Equation 5: } \\
& 6 \mathrm{MWD}_{\mathrm{m}}=416.1-\left(3.5 \times \text { age }_{\text {years }}\right)+ \\
& +\left(-1.9 \times \text { body }^{\text {mass }} \mathrm{kg}\right)+\left(310.1 \times \text { stature }_{\mathrm{m}}\right)+ \\
& +(40.8 \times \text { sex }) \text {. }
\end{aligned}
$$

The 6MWD and the 6MWD $\times$ body mass product were selected as important predictors of peak $\dot{\mathrm{V}} \mathrm{O}_{2}$ in different models, explaining between $41.1 \%$ and $56.9 \%$ of the peak $\dot{\mathrm{V}} \mathrm{O}_{2}$ total variability (Figure 3 ). 


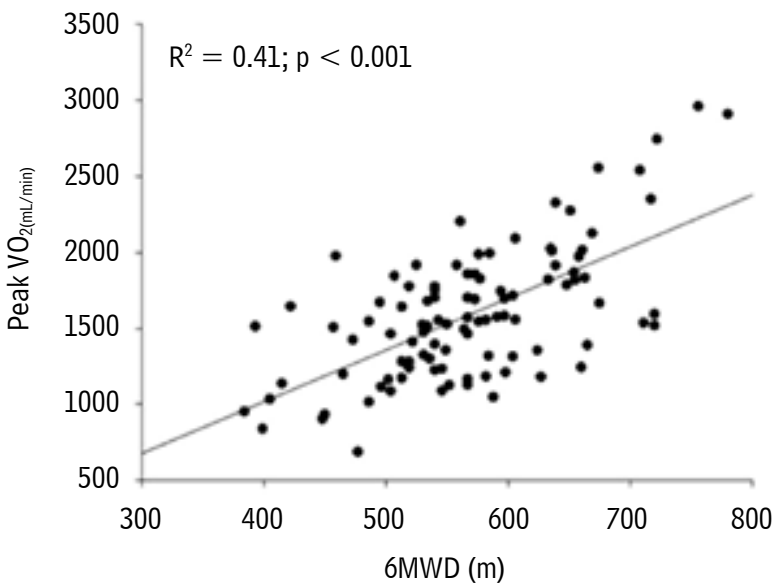

Prediction of the expected values: Peak $\mathrm{VO}_{2 \mathrm{~mL} / \mathrm{min}}=-341(3,3 \times 6 \mathrm{MWD})$ Prediction of the lower limit of normal: Peak $\mathrm{VO}_{2 \mathrm{~mL} / \mathrm{min}}=-892(3,3 \times 6 \mathrm{MWD})$

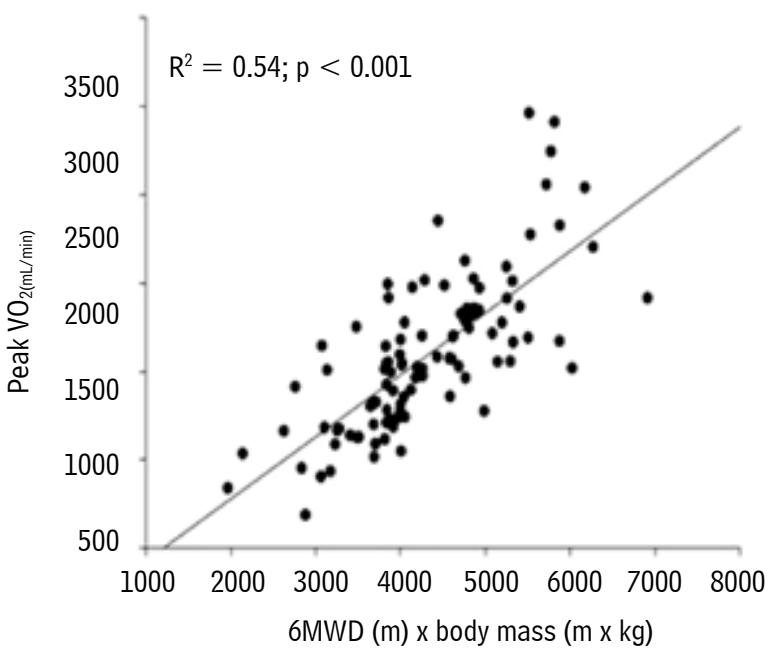

Prediction of the expected values: Peak $\mathrm{VO}_{2 \mathrm{~mL} / \mathrm{min}}=$

$=77+(0,035 \times 6 \mathrm{MWD}) \times$ body mass $\left.\mathrm{kg}_{\mathrm{g}}\right)$

Prediction of the lower limit of normal: Peak $\mathrm{VO}_{2 \mathrm{~mL} / \mathrm{min}}=$

$=-361+(0,035 \times 6$ MWD $) \times$ body mass $\left.{ }_{\mathrm{kg}}\right)$

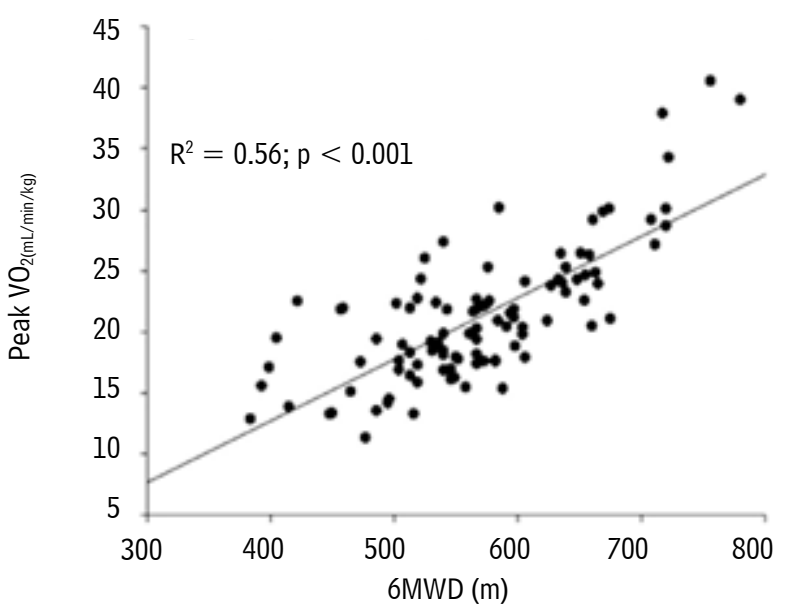

Prediction of the expected values: Peak $\mathrm{VO}_{2 \mathrm{~mL} / \mathrm{min} / \mathrm{kg}}=-7,4+(0,05 \times 6 \mathrm{MWD})$ Prediction of the lower limit of normal: Peak $\mathrm{VO}_{2 \mathrm{~mL} / \mathrm{min} / \mathrm{kg}}=-13,3+(0,05 \times 6 \mathrm{MWD})$

Figure 3 - Correlations between peak oxygen uptake $\left(\mathrm{V}_{2}\right)$ and 6-min walk distance (6MWD) in the studied sample.
The mean 6MWD and peak $\mathrm{V}_{2}$ in the 6MWT prospectively measured in 30 subjects were respectively $616 \pm 75 \mathrm{~m}$ and $1621 \pm 395 \mathrm{~mL} / \mathrm{min}$, representing $110 \pm 10 \%$ and $102 \pm 15 \%$ of the predicted values calculated with our reference equations. There were acceptable agreement (Figure 4), and the difference between prospectively measured and predicted values in these subjects was not significant regarding 6MWD and peak $\mathrm{VO}_{2}$ in the $6 \mathrm{MWT}$.
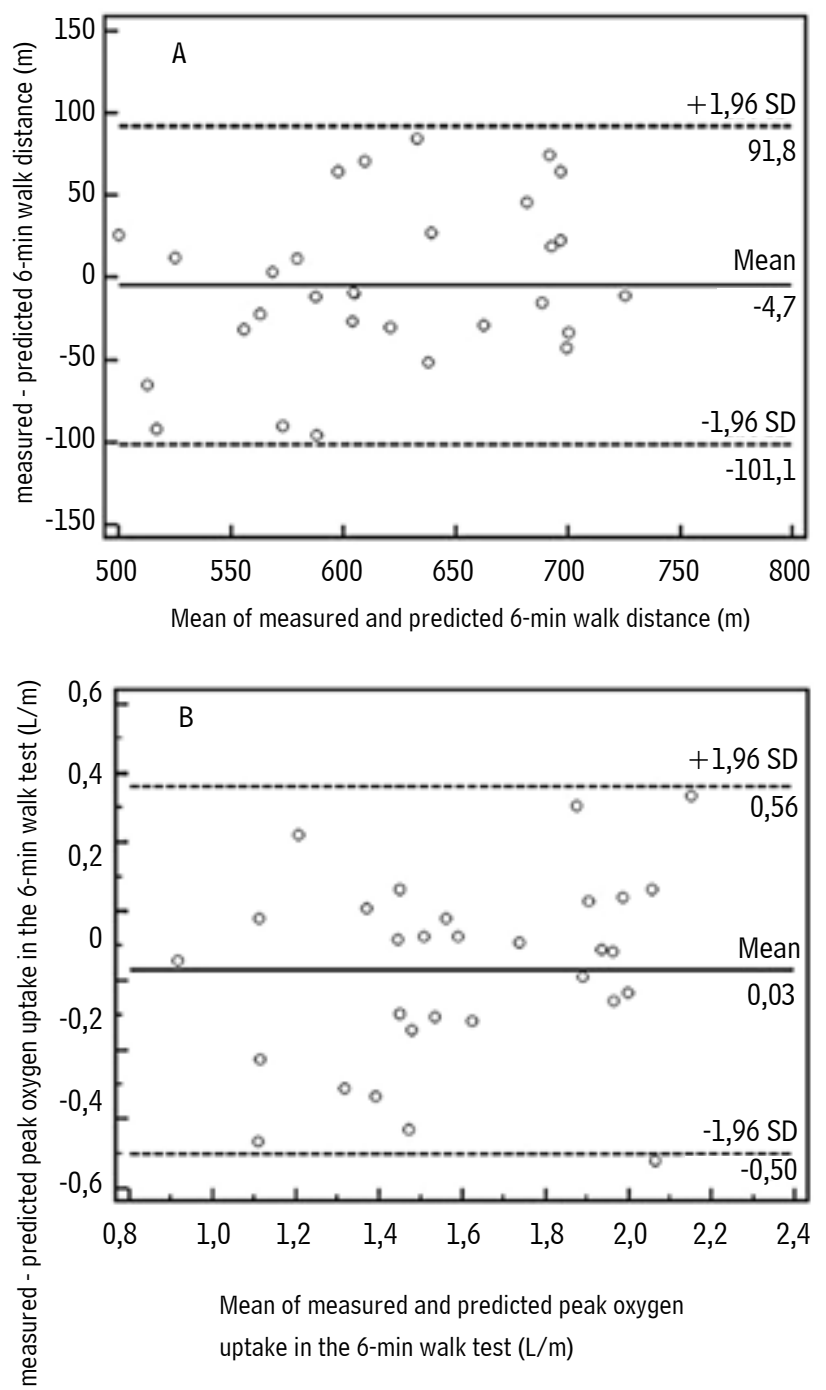

Figure 4-Agreement between measured and predicted total walking distance $(A)$ and peak oxygen uptake $(B)$ in the 6-min walk test in the 30 participants of the cross-validation sample.

In the cross-validation sample, peak $\dot{\mathrm{V}}_{2}$ was $30 \pm 10 \mathrm{~mL} / \mathrm{min} / \mathrm{kg}(108 \pm 18 \%$ of predicted values $)$ and peak HR was $156 \pm 15 \mathrm{bpm}$. The 6MWT intensity corresponded to $72 \pm 13 \%$ of peak $\dot{V}_{2}$ and $78 \pm 23 \%$ of peak HR in the CPET. Peak $\dot{\mathrm{VO}}_{2}$ in the 6MWT corresponded to $105 \pm 25 \%$ of the $\dot{\mathrm{V}}_{2}$ LT. Eighteen 
participants $(60 \%)$ presented peak $\dot{\mathrm{V}}_{2}$ in the $6 \mathrm{MWT}$ above the $\dot{\mathrm{VO}}_{2}$ LT. Peak $\mathrm{O}_{2}$ in the 6MWT and 6MWD correlated significantly with peak $\mathrm{VO}_{2}$ in the CPET $\left(\mathrm{R}^{2}=0.76 ; \mathrm{p}<0.001\right)$.

\section{Discussion}

In this study we derived a series of reference equations to predict the normal physiological responses induced by the 6MWT.

We may state that the 6MWT represents a moderate to high-intensity exercise regarding $\mathrm{HR}$ values around $80 \%$ of maximal. Kervio et al. [17] obtained similar results with 12 participants ( $64 \pm 1$ years old) using the same gas analyzer. The HR values reached $85 \%$ of maximal, and peak $\mathrm{V}_{2}$ during the third of up to fifth 6MWTs was quite similar to that of this study $\left(23 \pm 1 \mathrm{~mL} \mathrm{~min}^{-1} \mathrm{~kg}^{-1}\right)$. The authors also showed that the peak $\mathrm{VO}_{2}$ during the fifth $6 \mathrm{MWT}$ represented $80 \%$ of the peak $\mathrm{V}_{2}$ obtained in CPET performed on a treadmill compared to $72 \pm 13 \%$ in this study. Our participants were younger than the participants involved in the abovementioned study [17]. For our participants older than 60 years, the results were similar (data not shown). The results in patients with chronic diseases allow the classification of the 6MWT as a high-intensity test or even maximal in some clinical situations [18]. Although the peak $\mathrm{V}_{2}$ during the 6MWT is comparable to that observed in cycle ergometer CPET, the time course of the main variables presents an exponential pattern, as observed here and in previous studies both for healthy participants and for patients with chronic disease $[7,17,19]$.

Our results show consistent correlations between the 6MWD and peak $\mathrm{V}_{2}$ in the CPET. This consistent correlation has been described in several studies [17, $18,20,21]$. Although the 6MWT is not a constant workload test, the walking speed reaches a constant value from the third minute of the test onwards. Such a characteristic makes the 6MWT less accurate for predicting peak $\dot{\mathrm{V}}_{2}$ in CPET. Despite these limitations, our prediction equation seem to be accurate, as can be seen in the Figure 4. Moreover, non-linear models for 6MWD prediction have been described recently [22], but the results showed similar power of predictions compared to linear models.

There were influences of age, body mass, stature and sex in the main physiological variables studied. Several studies have reported these findings [17, 23-25]. The physiological responses to the 6MWT were predicted for independent variables similar to that described for CPET in Brazilian subjects [26]. Since there is a lack of literature about the normal physiology during constant workload exercise tests, our $\mathrm{R}^{2}$ values could not be compared properly.

We observed in this study that HGS had significant influence on 6MWD even after adjusting for age, body mass and stature. Our results are consistent with that of the literature. Several studies have demonstrated consistent correlation between HGS and 6MWD in patients with chronic obstructive pulmonary disease and in healthy or asymptomatic individuals $[27,28]$. This assessment is a useful indicator of different exercise programs effect in improving the strength of the hand and forearm muscles, as well as physical performance in sports performed predominantly by the upper limbs [29]. Furthermore, several chronic diseases have skeletal muscle dysfunction as an important clinical marker. The HGS-based equation presented here may be useful for predicting the 6MWD in such patients. On the other hand, body composition variables did not improve the power of the prediction models, besides not being as determinative as HGS for the most clinically used variables (i.e., peak $\mathrm{V}_{2}$ and $6 \mathrm{MWD}$ ). Neder et al. [26] reported similar results for cycle ergometer CPET. In this study, residuals of equations involving muscle strength and body composition were narrowed; however, the $\mathrm{R}^{2}$ was not sufficiently increased [26].

Based on the reliability analysis performed, our results suggest that there is a need for only one 6MWT for familiarization. This is in agreement with the recommendations of the ATS [13]. Hill et al. [19] also showed that 6MWD increased between the first and the second test but no further improvement on third test was observed in health adults aged 45 to 85 years. In contrast, Kervio et al. [17] performed five 6MWTs and found that at least 2 tests were necessary for familiarization. The differences between the protocols used for the 6MWT in our study and that used in the study by Kervio et al. [17], which was conducted before the ATS guidelines [13] were released, might explain the different findings.

This study has some limitations. We recruited a convenience sample. However, we took care to include only healthy individuals not involved in sports or vigorous physical activity. We did not find a significant influence of physical activity level on 6MWT performance. A recent study observed a significant association between the 6MWD and physical activity level [30] despite the controversy of this issue. 
Thus, the 6MWT represents a high-intensity test for most middle-aged and older healthy adults and, therefore, it is valid for assessing aerobic functional exercise capacity in this age group, considering the strong correlation between peaks $\mathrm{V}_{2}$ in the 6MWT and in the CPET on this study. Physiological responses to the 6MWT may be adequately predicted with a combination of anthropometrics, demographics and muscle properties. These results, therefore, might provide a more appropriate frame of reference for the normality of physiological responses to the 6MWT in healthy adults aged 40 years and older.

\section{References}

1. Society ER. Clinical exercise testing with reference to lung diseases: indications, standardization and interpretation strategies. ERS Task Force on Standardization of Clinical Exercise Testing. European Respiratory Society. Eur Respir J. 1997;10(11):2662-89.

2. Woods PR, Frantz RP, Taylor BJ, Olson TP, Johnson BD. The usefulness of submaximal exercise gas exchange to define pulmonary arterial hypertension. J Heart Lung Transplant. 2011;30(10):1133-42.

3. Maher CA, Williams MT, Olds TS. The six-minute walk test for children with cerebral palsy. Int J Rehabil Res. 2008;31(2):185-8.

4. Paap E, van der Net J, Helders PJ, Takken T. Physiologic response of the six-minute walk test in children with juvenile idiopathic arthritis. Arthritis Rheum. 2005;53(3):351-6.

5. Vis JC, Thoonsen H, Duffels MG, Bruin-Bon RA, Huisman SA, van Dijk AP, et al. Six-minute walk test in patients with Down syndrome: validity and reproducibility. Arch Phys Med Rehabil. 2009;90(8):1423-7.

6. Vis JC, Thoonsen H, Duffels MG, Bruin-Bon RA, Huisman SA, van Dijk AP, et al. Six-minute walk test in patients with Down syndrome: validity and reproducibility. Arch Phys Med Rehabil. 2009;90(8):1423-7.

7. Troosters T, Vilaro J, Rabinovich R, Casas A, Barberà JA, Rodriguez-Roisin R, et al. Physiological responses to the 6-min walk test in patients with chronic obstructive pulmonary disease. Eur Respir J. 2002;20(3):564-9.
8. Bautista J, Ehsan M, Normandin E, Zuwallack R, Lahiri B. Physiologic responses during the six minute walk test in obese and non-obese COPD patients. Respir Med. 2011;105(8):1189-94.

9. Miller MR, Hankinson J, Brusasco V, Burgos F, Casaburi $\mathrm{R}$, Coates A, et al. Standardisation of spirometry. Eur Respir J. 2005;26(2):319-38.

10. Thomas S, Reading J, Shephard RJ. Revision of the Physical Activity Readiness Questionnaire (PAR-Q). Can J Sport Sci. 1992;17(4):338-45.

11. Kyle UG, Bosaeus I, Lorenzo AD, Deurenberg P, Elia M, Gómez JM, et al. Bioelectrical impedance analysis: review of principles and methods. Clin Nutr. 2004;23(5):1226-43.

12. Mathiowetz V, Kashman N, Volland G, Weber K, Dowe M, Rogers S. Grip and pinch strength: normative data for adults. Arch Phys Med Rehabil. 1985;66(2):69-74.

13. ATS Committee on Proficiency Standards for Clinical Pulmonary Function Laboratories. ATS statement: guidelines for the six-minute walk test. Am J Respir Crit Care Med. 2002;166(1):111-7.

14. Dourado VZ, Vidotto MC, Guerra RL. Reference equations for the performance of healthy adults on field walking tests. J Bras Pneumol. 2011;37(5):607-14.

15. Borg GA. Psychophysical bases of perceived exertion. Med Sci Sports Exerc. 1982;14(5):377-81.

16. Wasserman K, Hansen JE, Sue DY, Stringer WW, Sietsema K, Xing-Guo S, et al. Principles of exercise testing and interpretation. 5a ed. Philadelphia: Lippincott Williams \& Wilkins; 2011.

17. Kervio G, Carre F, Ville NS. Reliability and intensity of the six-minute walk test in healthy elderly subjects. Med Sci Sports Exerc. 2003;35(1):169-74.

18. Singh SJ. Walking for the assessment of patients with chronic obstructive pulmonary disease. Eur Respir Mon. 2007;40(1):148-64. 
19. Hill K, Wickerson LM, Woon LJ, Abady AH, Overend TJ, Goldstein RS, et al. The 6-min walk test: responses in healthy Canadians aged 45 to 85 years. Appl Physiol Nutr Metab. 2011;36(5):643-9.

20. Carvalho EE, Costa DC, Crescêncio JC, Santi GL, Papa V, Marques F, et al. Heart failure: comparison between six-minute walk test and cardiopulmonary test. Arq Bras Cardiol. 2011;97(1):59-64.

21. Turner SE, Eastwood PR, Cecins NM, Hillman DR, Jenkins SC. Physiologic responses to incremental and self-paced exercise in COPD: a comparison of three tests. Chest. 2004;126(3):766-73.

22. Dourado VZ, McBurnie MA. Allometric scaling of 6-min walking distance by body mass as a standardized measure of exercise capacity in healthy adults. Eur J Appl Physiol. 2012;112(7):2503-10.

23. Casanova C, Celli BR, Barria P, Casas A, Cote C, Torres JP, et al. The 6-min walk distance in healthy subjects: reference standards from seven countries. Eur Respir J. 2011;37(1):150-6.

24. Luxton N, Alison JA, Wu J, Mackey MG. Relationship between field walking tests and incremental cycle ergometry in COPD. Respirology. 2008;13(6):856-62.

25. Pepera GK, Sandercock GR, Sloan R, Cleland JJ, Ingle L, Clark AL. Influence of step length on 6-minute walk test performance in patients with chronic heart failure. Physiotherapy. 2012;98(4):325-9.
26. NederJA, Nery LE, Castelo A, AndreoniS, Lerario MC, Sachs A, et al. Prediction of metabolic and cardiopulmonary responses to maximum cycle ergometry: a randomised study. Eur Respir J. 1999;14(6):1304-13.

27. Dourado VZ, Antunes LC, Tanni SE, Paiva SA, Padovani CR, Godoy I. Relationship of upper-limb and thoracic muscle strength to 6-min walk distance in COPD patients. Chest. 2006;129(3):551-7.

28. Enright PL, McBurnie MA, Bittner V, Tracy RP, McNamara R, Arnold A, et al. The 6-min walk test: a quick measure of functional status in elderly adults. Chest. 2003;123(2):387-98.

29. Mermier CM, Janot JM, Parker DL, Swan JG. Physiological and anthropometric determinants of sport climbing performance. Br J Sports Med. 2000;34(5):359-65.

30. Steffens D, Beckenkamp PR, Hancock M, Paiva DN, Alison JA, Menna-Barreto SS. Activity level predicts 6-minute walk distance in healthy older females: an observational study. Physiotherapy. 2013;99(1):21-6.

Received 01/09/2019 Recebido em 09/01/2019 Recibido en 09/01/2019

Approved 07/22/2019 Aprovado em 22/07/2019 Aprobado en 22/07/2019 